\title{
IMPLEMENTASI TAX PLANNING TERHADAP PERHITUNGAN PPh BADAN PADA PT CITRA ABADI SEJATI
}

\author{
Wiwik Budianti \\ Dosen Tetap Fakultas Ekonomi Universitas Pakuan \\ Ihda Okta Evi Ana \\ Mahasiswa Fakultas Ekonomi Universitas Pakuan
}

\begin{abstract}
ABSTRAK
Tujuan penelitian ini adalah untuk mengetahui (1) gambaran kebijakan penyusutan aset tetap pada PT. Citra Abadi Sejati, (2) penerapan metode penyusutan aset tetap pada PT. Citra Abadi Sejati dengan metode alternatif sesuai dengan ketentuan perpajakan, (3) apa pengaruh penerapan perencanaan pajak aset tetap terhadap efisiensi beban pajak penghasilan badan pada PT. Citra Abadi Sejati. Jenis penelitian yang digunakan dalam skripsi ini adalah Penelitian Eksplanatori dengan metode penelitian studi kasus, dan teknik penelitian analisis kuantitatif. Untuk memperoleh data dan informasi yang diperlukan, maka penulis melakukan penelitian terhadap unit analisis pada PT. Citra Abadi Sejati, yaitu sumber data dan informasi yang diperoleh dari bagian Akuntansi. Dari hasil penelitian dapat disimpulkan bahwa implementasi tax planning terhadap aset tetap berpengaruh terhadap efisiensi beban pajak peghasilan badan dan saran yang dapat penulis berikan adalah agar perusahaan melakukan perencanaan pajak terhadap aset tetapnya dengan memilih metode penyusutan garis lurus sehingga dapat memperkecil beban pajak penghasilannya.
\end{abstract}

Kata Kunci: Implementasi Tax Planning, Perhitungan PPh Badan

\begin{abstract}
The purpose of this study was to determine (1) the image policy of depreciation of fixed assets at PT. Citra Abadi Sejati, (2) application of the method of depreciation of fixed assets at PT. Citra Abadi Sejati with alternative methods in accordance with tax regulations, (3) what the effect of the application of the tax planning of fixed assets to the efficiency of corporate income tax expense in the PT. Citra Abadi Sejati. This type of research used in this research is explanatory research with case study method, quantitative analysis and research techniques. To obtain the necessary data and information, the authors conducted research on the analysis unit at PT. Citra Abadi Sejati, which is the source of the data and information obtained from the accounting. From the results of this study concluded that the implementation of tax planning to the fixed assets affect the efficiency of the tax burden peghasilan bodies and suggestions to the authors give is that corporation tax planning on its fixed assets by selecting the straight-line depreciation method so as to minimize the burden of income tax.
\end{abstract}

Kerywords: Tax Planning and Tax Income Corporate

\section{Pendahuluan}

Penghindaran pajak adalah perbuatan legal yang masih dalam ruang lingkup perpajakan dan tidak melanggar ketentuan peraturan perundangundangan perpajakan. Sesungguhnya antara penghindaran pajak dan penggelapan pajak terdapat perbedaan yang fundamental, akan tetapi kemudian perbedaan tersebut menjadi kabur baik secara teori maupun aplikasinya.

Secara konseptual justru dalam menentukan perbedaan antara penghindaran pajak dan penyelundupan pajak, kesulitannya terletak pada penentuan perbedaannya, akan tetapi berdasarkan konsep perundangundangan, garis pemisahnya adalah 
antara melanggar undang-undang (unlawful) dan tidak melanggar undangundang (lawful). Oleh karena itu, dalam perencanaan pajak hendaknya bersikap lebih hati-hati agar perbuatan penghindaran pajaknya tidak dianggap sebagai partisipan atau sekongkol dalam perbuatan yang dapat dianggap sebagai penggelapan pajak (tindak pidana fiskal) karena tidak ada batasan yang jelas antara penghindaran pajak dan penggelapan pajak.

Tax planning merupakan upaya legal yang bisa dilakukan Wajib Pajak. Tindakan itu legal karena pengghematan pajak tersebut dilakukan dengan cara yang tidak melanggar ketentuan yang berlaku.

Upaya-upaya yang dapat dilakukan dalam melakukan tax planning dalam meminimalkan jumlah Pajak Penghasilan $(\mathrm{PPh})$ terutang Badan, yaitu dengan memaksimalkan penghasilan yang dikecualikan, memaksimalkan biaya fiskal meminimalkan biaya yang tidak diperkenankan pengurang serta pemilihan metode akuntansi yang sesui dengan perencanaan.

Penelitian sebelumnya yang dilakukan oleh Erni Ramayanti (2010) didapatkan bahwa PT Agricon Putra Citra Optima (APCO) merupakan perusahaan yang berbentuk badan perseroan terbatas dan bergerak di bidang jasa pengendalian rayap dan hama, memilki tujuan yang sama yaitu untuk mencapai laba yang maksimal secara terus-menerus. Salah satunya dengan melakukan perencanaan pajak guna mengefesienkan pembayaran pajak terhutang. Dengan melaksanakan tax planning, perusahan akan terbantu dalam melakukan perencanaan kegiatan operasi

\section{Tinjauan Pustaka}

\subsection{Manajemen Pajak}

Suandy Perencanaan Pajak $(2013,6)$ Manajemen Pajak adalah sarana untuk perusahaan dan pengambilan keputusan untuk pencapaian laba maksimum dan peningkatan kinerja perusahaan untuk tetap eksis dan menjadi perusahaan yang bijak dan taat pajak serta dapat mengupdate peraturan perpajakan yang berlaku.

Penelitian yang dilakukan oleh Irnia Dina Rosa (2014) menunjukkan hasil dari penelitian perencanaan pajak atas aktiva tetap pada PT X Surabaya sebenarnya dapat dilakukan dengan cara memilih metode penyusutan aktiva tetap secara tepat, yaitu dengan menggunakan Metode Penyusutan Saldo Menurun. Penggunaan Metode Penyusutan Saldo Menurun, setelah dilakukan perhitungan ditemukan bahwa pajak yang dibayarkan lebih kecil, atau dengan kata lain dapat menghemat pembayaran pajak.

PT Citra Abadi Sejati adalah perusahaan yang bergerak dibidang industri garment yang beralamat di Jalan Raya Kedung Halang No. 263 Km 52 Bogor 16710. PT Citra Abadi Sejati merupakan perusahaan yang sebelumnya bernama PT Busana perkasa Garment kemudian ada perubahan kepemilikan sehingga sekarang Berganti nama PT Citra Abadi Sejati dan telah berjalan selama 6 tahun.

Ada pun tujuan penelitian ini adalah: 1) Untuk mengetahui pelaksanaan kewajiban perpajakannya secara efektif dan efisien berdasarkan peraturan perpajakan yang berlaku; 2) Untuk menjelaskan gambaran kebijakan penyusutan aset tetap pada PT Citra Abadi Sejati; dan 3) Untuk menjelaskan apa pengaruh penerapan perencanaan pajak aset tetap terhadap efisiensi beban pajak penghasilan badan pada PT Citra Abadi Sejati.

memenuhi kewajiban perpajakan dengan benar tetapi jumlah pajak yang dibayar dapat ditekan serendah mungkin untuk memperoleh laba dan likuiditas yang diharapkan. Tujuan manajemen pajak 
dapat dibagi menjadi dua yaitu: (Suandy, 2013, 6).

1. Menerapkan peraturan perpajakan secara benar.

2. Usaha efisiensi untuk mencapai laba dan likuiditas yang seharusnya.

Tujuan manajemen pajak dapat dicapai melalui fungsi - fungsi manajemen pajak yang terdiri atas:

1. Perencanaan pajak (tax planning).

2. Pelaksanaan kewajiban perpajakan (tax implementation).

3. Pengendalian pajak (tax control).

\subsection{Perencanaan Pajak (Tax planning)}

Perencanaan pajak merupakan langkah awal dalam manajemen pajak. Pada tahap ini dilakukan pengumpulan dan penelitian terhadap peraturan perpajakan agar dapat diseleksi jenis tindakan penghematan yang akan dilakukan. Pada umumnya penekanan perencanaan pajak adalah untuk meminimumkan kewajiban pajak.

Mengemukakan

untuk meminimumkan kewajiban pajak dapat dilakukan dengan berbagai cara baik yang masih memenuhi ketentuan perpajakan (lawful) maupun yang melanggar peraturan perpajakan (unlawful). Ukuran yang digunakan dalam mengukur kepatuhan peraturan wajib pajak adalah sebagai berikut: (Suandy, 2013, 7)

1. Tax saving upaya Wajib Pajak mengelakkan hutang pajaknya dengan jalan menahan diri untuk tidak membeli produk - produk yang ada pajak pertambahan nilainya atau dengan sengaja mengurangi jam kerja atau pekerjaan yang dapat dilakukannya sehingga penghasilannya menjadi kecil dan dengan demikian terhindar dari pengenaan pajak penghasilan yang besar.
2. Tax avoidance yaitu upaya Wajib Pajak untuk tidak melakukan perbuatan yang dikenakan pajak atau upaya-upaya yang masih dalam kerangka ketentuan peraturan perundang-undangan perpajakan untuk memperkecil jumlah pajak yang terhutang.

Tujuan Tax Planning

a. Menghilangkan/menghapus pajak sama sekali;

b. Menghilangkan/menghapus pajak dalam tahun berjalan;

c. Menunda pengakuan penghasilan;

d. Mengubah penghasilan rutin berbentuk capital gain (keuntungan modal) yang berupa keuntungan atau laba yang diperoleh dari investasi dalam surat berharga atau efek seperti saham atau dalam bidang property, dimana nilainya melebihi harga pembelian.

Manfaat perencanaan pajak pada prinsipnya adalah sebagai berikut:

1. Mengatur alur kas merupakan perencanaan yang dapat mengestimasi kebutuhan kas untuk pajak dan menentukan saat pembayaran sehingga perusahaan dapat menyusun anggaran kasnya dengan lebih akurat.

2. Penghematan kas keluar adalah perencanaan pajak yang dapat menghemat pajak yang merupakan biaya bagi perusahaan.

Prinsip - prinsip untuk menghemat pajak: (Suandy, 2013, 6).

1. Memanfaatkan secara optimal ketentuan-ketentuan perpajakan yang berlaku.

2. Menyebar penghasilan kebeberapa tahun untuk menghindari pajak yan tinggi.

3. Mengambil beberapa keuntungan dari pemilihan bentuk-bentuk 
usaha yang tepat. Usaha untuk menghemat pajak pada dasarnya berusaha menekan jumlah pajak sekecil mungkin dan menunda pembayaran pajak selambat mungkin.

4. Mendirikan perusahaan dalam satu jalur usaha sehingga dapat diukur secara keseluruhan penggunaan tarif pajak dan potensi penghasilannya, dilihat dari segi perpajakan pembagian pajak atas perusahaan memberikan manfaat penghematan pajak.

Menurut pendapat Suandy (2013, 10), motivasi dilakukannya perencanaan pajak pada umumnya bersumber dari tiga unsur perpajakan yaitu:

1. Kebijakan Perpajakan (Tax Policy), merupakan alternatif dari berbagai sasaran yang menjadi tujuan dalam sistem perpajakan. Faktor-faktor yang mendorong dilakukannya suatu perencanaan pajak, antara lain :

a. Jenis Pajak yang akan dipungut.

b. Subjek Pajak.

c. Objek Pajak.

d. Besarnya Tarif Pajak.

e. Prosedur pembayaran pajak.

2. Undang-undang Perpajakan (Tax Law). Tidak ada undang-undang yang mengatur setiap permasalahan secara sempurna. Oleh karena itu, dalam pelaksanaannya selalu diikuti oleh ketentuanketentuan lain, seperti Peraturan Pemerintah, Keputusan Presiden, Keputusan Menteri Keuangan, dan Keputusan Direktur Jenderal Pajak.
Sering terjadi pertentangan antara ketentuan pelaksanaan tersebut dengan undangundang itu sendiri karena adanya penyesuaian dengan kepentingan pembuat kebijakan dalam mencapai tujuan lain yang ingin dicapainya. Akibatnya terbuka celah (loopholes) bagi Wajib Pajak untuk menganalisis dengan cermat kesempatan tersebut untuk melakukan perencanaan pajak yang baik.

3. Administrasi Perpajakan (Tax Administration). Indonesia sebagai negara yang sedang membangun masih mengalami kesulitan dalam melaksanakan administrasi perpajakannya secara memadai. Hal ini mendorong perusahaan untuk melaksanakan perencanaan dengan baik untuk menghindari sanksi administrasi maupun pidana yang diakibatkan karena adanya perbedaan penafsiran antara aparat fiskus dengan perusahaan selaku Wajib Pajak karena luasnya peraturan perpajakan yang berlaku dan sistem informasi yang belum efektif.

\section{Metodologi Penelitian \\ 3.1. Jenis Penelitian}

Metode yang digunakan dalam penelitian ini adalah metode analisis dekskriptif kuantitatif. Penelitian yang dilakukan pada PT Citra Abadi Sejati ini digolongkan dalam studi kasus. Dalam penelitian studi kasus ini tidak sampai mempermasalahkan hubungan antara variabel - variabel yang ada, dan juga tidak dimaksudkan untuk menarik suatu 
generalisasi yang menjelaskan variabel yang menyebabkan suatu gejala atau kenyataan sosial.

\subsection{Objek, Unit Analisis, dan Lokasi Penelitian}

1. Objek Penelitian

Sebagai objek yang dianalisis dalam penelitian adalah Implementasi Tax Planning Terhadap Perhitungan PPh Badan Pada PT Citra Abadi Sejati. Saya memilih Tax Planning Perhitungan $\mathrm{PPh}$ badan mengingat pentingnya penerapan Tax Planning dalam perencanaan peminimalan pembayaran pajak badan. Dengan kata lain penerapan tax planning mempengaruhi beban pajak penghasilan badan.

2. Unit analisis

Yang diteliti adalah suatu organisasi, sehingga data adalah mengenai atau berasal dari bagian pajak yang berada di dalam PT Citra Abadi Sejati.

3. Lokasi penelitian

Penelitian ini dilakukan di PT Citra Abadi Sejati yang bergerak dibidang garment beralamat di jalan Raya Kedung Halang No 263 Km 52 Bogor 16710. Tempat penelitian tersebut dipilih dengan pertimbangan bahwa baik data maupun informasi yang dibutuhkan dapat diperoleh serta relevan dengan pokok permasalahan yang menjadi objek penelitian.

\subsection{Jenis dan Sumber Data Penelitian}

Jenis-jenis data yang digunakan dalam penelitian ini adalah :

1. Data kualitatif yaitu data yang berisi kondisi perusahaan seperti latar belakang perusahaan, struktur organisasinya, tujuan perusahaan, rencana perusahaan, kebijakan perusahaan. Data tersebut dapat diperoleh secara lisan ataupun tulisan.

2. Data kuantitatif yaitu data yang berbentuk dokumen, daftar atau angaka-angka yang dapat dihitung berupa laporan keuangan perusahaan.

Sumber data yang digunakan dalam penelitian ini adalah:

1. Data primer yaitu data yang diperoleh langsung dengan melakukan wawancara dan observasi pada perusahaan sebagai objek penelitian.

2. Data sekunder yaitu data yang berupa catatan-catatan perusahaan dan lampiran-lampiran serta literature yang berhubungan dengan penelitian ini.

\subsection{Operasionalisasi Variabel}

Penjabaran masing-masing variabel ke dalam indikator, ukuran dan skala data, dapat ditampilkan dalam bentuk tabel sebagai berikut:

Tabel 1.

Operasionalisasi Variabel

\begin{tabular}{|c|c|c|c|}
\hline Variabel Utama & Indikator & Ukuran & Skala \\
\hline $\begin{array}{l}\text { Variable Independen }(\mathrm{X}) \\
\text { Penerapan Perencanaan } \\
\text { Pajak } \\
\text { Sub Variabel: } \\
\text { a. Aspek Formal }\end{array}$ & $\begin{array}{l}\text { Kepatuhan wajib } \\
\text { pajak badan }\end{array}$ & $\begin{array}{l}\text { a. Mendaftarkan diri untuk } \\
\text { mendapatkan NPWP, mengisi } \\
\text { dan memasukkan SPT ke }\end{array}$ & Nominal \\
\hline
\end{tabular}

JAFE (Jurnal Ilmiah Akuntansi Fakultas Ekonomi)

Volume 2 No. 1 Tahun 2016 Edisi 1, Hal. 66-76 


\begin{tabular}{|c|c|c|c|}
\hline $\begin{array}{l} \\
\text { Perencanaan pajak untuk } \\
\text { aset tetap }\end{array}$ & $\begin{array}{l}\text { b. Adanya biaya- } \\
\text { biaya yang dapat } \\
\text { dikurangkan dari } \\
\text { penghasilan bruto } \\
\text { menurut Undang- } \\
\text { Undang } \\
\text { Perpajakan. } \\
\text { - Harga } \\
\text { perolehan } \\
\text { - Estimasi masa } \\
\text { manfaat } \\
\text { - Estimasi nilai } \\
\text { residu } \\
\text { - Metode } \\
\text { penyusutan }\end{array}$ & $\begin{array}{l}\text { Direktorat Jenderal Pajak } \\
\text { b. Mengalihkan biaya yang tidak } \\
\text { boleh dikurangkan dari } \\
\text { pengahasilan bruto perusahaan } \\
\text { ke biaya yang dapat } \\
\text { dikurangkan dari penghasilan } \\
\text { bruto perusahaan sesuai UU } \\
\text { PPh yang berlaku dengan } \\
\text { rekonsiliasi fiskal. } \\
\text { Pengeluaran modal awal saat } \\
\text { perolehan aset : } \\
\text { Harga Aset }+ \text { Biaya-biaya yang } \\
\text { menyertai } \\
\text { Pertimbangan Tahun } \\
\text { Nilai Tunai/Nol } \\
\text { Metode Garis Lurus : } \\
\quad \text { HP-NR } \\
\text { UE } \\
\text { Metode Saldo Menurun : } \\
\text { Tarif x Nilai Buku Awal Tahun. }\end{array}$ & Rasio \\
\hline $\begin{array}{l}\text { Variable Dependen } \\
\text { ( Y ) } \\
\text { PPh Badan } \\
\text { Penghasilan Bruto } \\
\text { Pengenaan pajak penghasil } \\
\text { Natura atau kenikmatan } \\
\text { Beban- beban yang } \\
\text { dikurangkan penghasil bruto } \\
\text { Biaya - biya yang tidak } \\
\text { boleh dibebankan }\end{array}$ & $\begin{array}{l}\text { Pasal } 4 \text { ayat } 1 \\
\text { Pasal } 4 \text { ayat } 2 \\
\text { Pasal } 4 \text { ayat } 3 \\
\text { Pasal } 6 \\
\text { Pasal } 9 \\
\text { Pasal } 17 \\
\begin{array}{l}\text { Penghematan Beban } \\
\text { pajak penghasilan } \\
\text { badan }\end{array}\end{array}$ & $\begin{array}{l}\text { Penghasilan } \\
\text { Pajak Penghasilan final } \\
\text { Pengecualian Sebagai Objek Pajak } \\
\text { Pengurangan Objek Pajak } \\
\text { Pengecualian Sebagai Pengurang } \\
\text { Objek Pajak } \\
\text { Tarif Pajak } \\
\begin{array}{l}\text { Jumlah PPh Badan yang dapat } \\
\text { dihemat }\end{array}\end{array}$ & Rasio \\
\hline
\end{tabular}

\subsection{Metode Penarikan Sampel}

Populasi penelitian ini adalah rincian laporan laba rugi PT Citra Abadi Sejati. Sampel yang di ambil adalah rincian laporan laba rugi yang berakhir pada 31 Desember 2012.

\subsection{Metode Pengumpulan Data}


1. Survey yaitu mewawancarai langsung bagian pajak yang ada di PT Citra abadi sejati

2. Observasi yaitu mendatangi PT Citra Abadi Sejati

3. Analisis dan Pengolah Data

\subsection{Metode Pengolahan/Analisis Data}

Metode analisis data yang digunakan dalam penelitian ini adalah metode analisis dekskriptif kuantitatif tanpa menggunakan analisis statistik, yaitu menaganalisis, mengumpulkan dan melihat implementasi tax planning terhadap perhitungan $\mathrm{PPh}$ badan pada PT Citra Abadi Sejati.

\section{Hasil dan Pembahasan}

4.1. Kebijakan penyusutan aset tetap.

1. Pengukuran dan pengakuan

Efektif tanggal 1 Januari 2012 grup telah memilih metode biaya untuk pengukuran aset tetapnya. Aset tetap yang diperoleh dengan cara dibangun sendiri nilainya diakui sebesar akumulasi total biaya aset saat pengerjaan pembangunan atau pembuatan dan pada saat aset berada pada lokasi dan keadaan yang diinginkan supaya aset siap digunakan sesuai dengan maksud manajemen perusahaan.

Sedangkan pengakuanya aset tetap yang dibeli diakui sebesar biaya perolehannya. Yang termasuk dalam biaya perolehannya adalah bea masuk, biaya pengangkutan, biaya penanganan, biaya penyimpanan, biaya penyediaan lokasi, biaya pemasangan, biaya upah tenaga kerja internal, estimasi awal biaya pembongkaran, pemindahan aset tetap dan restorasi lokasi aset tetap. Aset tetap yang diperoleh melalui sewa pembiayaan diakui pada saat aset tetap diterima sebesar nilai tunai angsuran ditambah nilai tunai opsi pembelianya pada akhir masa sewa pembiayaan.

2. Penyusutan

Penyusutan dihitung dengan menggunakan metode garis lurus (straightline method) berdasarkan umur ekonomis atau masa manfaat aset tetap yang bersangkutan. Masa manfaat ekonomis untuk masing-masing aset tetap ditetapkan sebagai berikut:

\begin{tabular}{|l|c|}
\hline Aset Group & $\begin{array}{c}\text { Useful Life } \\
\text { (Tahun) }\end{array}$ \\
\hline Bangunan & 20 \\
\hline Mesin & 4 \\
\hline Kendaraan & 4 \\
\hline $\begin{array}{l}\text { Inventaris } \\
\text { Kantor }\end{array}$ & 4 \\
\hline
\end{tabular}

Aset dalam penyelesaian dinyatakan sebesar biaya perolehan. Akumulasi biaya perolehan akan dipindahkan ke 
masing-masing aset tetap yang bersangkutan pada saat selesai dan siap digunakan.

\subsection{Penerapan metode Penyusutan aset tetap dengan metode alternatif yang sesuai dengan peraturan perpajakan}

Tabel 1

Perbandingan Beban Penyusutan dengan Metode garis Lurus dengan Metode Saldo Menurun (Disajikan dalam US Dollar)

\begin{tabular}{|c|c|c|c|c|}
\hline Metode & $\begin{array}{c}\text { Beban } \\
\text { Penyusutan } \\
2010\end{array}$ & $\begin{array}{c}\text { Beban } \\
\text { Penyusutan } \\
2011\end{array}$ & $\begin{array}{c}\text { Beban } \\
\text { Penyusutan } \\
2012\end{array}$ & $\begin{array}{c}\text { Beban } \\
\text { Penyusutan } \\
2013\end{array}$ \\
\hline Garis Lurus & $\$ 5,504,724.40$ & $5,565,735.66$ & $\$ 6,496,135.42$ & $6,723,898.64$ \\
\hline Saldo & $\$$ & $\$$ & & $\$$ \\
Menurun & $15,118,918.14$ & $5,663,473.07$ & $\$ 2,167,125.49$ & $2,616,887.10$ \\
\hline
\end{tabular}

(Sumber: PT. Citra Abadi Sejati, data diolah penulis)

Jika dilihat dari Tabel 1 perbandingan kedua metode penyusutan aset tetap tersebut di atas dapat disimpulkan jika menggunakan metode garis lurus menghasilkan beban penyusutan yang lebikecil dan seperti diketahui bahwa beban penyusutan merupakan salah satu pengurang dari profit atau penghasilan bruto, sehingga beban pajak penghasilan atau PPh yang di bayarkan perlu diperhitungkan sehingga mencari celah dalam menghemat pajak.

\subsection{Penghematan Pajak Dari Perbandingan Antara Metode Garis Lurus dan SaldoMenurun Dengan Present Value}

Berikut ini adalah perbandingan metode penyusutan garis lurus dan saldo menurun dengan menggunakan present value jika dengan penetapan diskon faktor yang di ambil dari suku bunga bank indonesia untuk tahun 2010 adalah sebesar 6,5\%, 2011 sebesar 6\%, 2012 sebesar $5,75 \%$ dan pada tahun 2013 sebesar $7.5 \%$.

Tabel 2

PT. Citra Abadi Sejati

Perbandingan Penghematan Beban Pajak Penghasilan antara Metode Garis

Lurus dan Metode Saldo Menurun dengan Present Value

Tahun 2010-2013

(Disajikan dalam US Dollar)

\begin{tabular}{|c|l|c|c|c|c|c|}
\hline No. & \multicolumn{1}{|c|}{$\begin{array}{c}\text { Aset Tetap } \\
\mathbf{2 0 1 0}\end{array}$} & \multicolumn{2}{c|}{$\begin{array}{c}\text { PV } \\
\text { Garis Lurus }\end{array}$} & \multicolumn{2}{c|}{$\begin{array}{c}\text { PV } \\
\text { Saldo Menurun }\end{array}$} & \multicolumn{2}{|c|}{ Selish } & \multicolumn{2}{|c|}{ Penghematan PPh } \\
\hline 1 & Mesin & $\$ 4,094,926.59$ & $\$ 8,189,853.19$ & $\$ 4,094,926.60$ & $\$ 1,023,731.65$ \\
\hline 2 & Inventaris Kantor & $\$$ & $854,864.96$ & $\$ 1,709,729.92$ & $\$ 854,864.96$ & $\$ 213,716.24$ \\
\hline 3 & Kendaraan & $\$ 169,851.21$ & $\$ 4,814,313.46$ & $\$ 4,644,462.25$ & $\$ 1,161,115.56$ \\
\cline { 6 - 8 }
\end{tabular}




\begin{tabular}{|c|c|c|c|c|c|c|c|}
\hline 4 & Bangunan dan Listrik & $\$$ & $385,081.64$ & $405,021.57$ & $\$$ & $19,939.93$ & $4,984.98$ \\
\hline \multirow[t]{2}{*}{5} & Masjid & & & & & & \\
\hline & Total & \multicolumn{2}{|c|}{$\$ 5,504,724.40$} & $\$ 15,118,918.14$ & \multicolumn{2}{|c|}{$\$ 9,614,193.74$} & $\$ \quad 2,403,548.44$ \\
\hline & $\begin{array}{c}\text { Aset Tetap } \\
2011\end{array}$ & \multicolumn{2}{|r|}{$\begin{array}{c}\text { PV } \\
\text { Garis Lurus } \\
\end{array}$} & $\begin{array}{c}\text { PV } \\
\text { Saldo } \text { Menurun }\end{array}$ & \multicolumn{2}{|r|}{ Selish } & Penghematan PPh \\
\hline 1 & Mesin & $\$$ & $4,114,242.28$ & $\$ 4,114,242.29$ & $\$$ & 0.01 & 0.00 \\
\hline 2 & Inventaris Kantor & $\$$ & $874,883.08$ & $890,868.83$ & $\$$ & $15,985.75$ & $3,996.44$ \\
\hline 3 & Kendaraan & $\$$ & $187,822.27$ & $\$ \quad 284,738.66$ & $\$$ & $96,916.39$ & $24,229.10$ \\
\hline 4 & Bangunan dan Listrik & $\$$ & $387,006.54$ & $\$ \quad 371,841.80$ & $\$$ & $(15,164.74)$ & $(3,791.19)$ \\
\hline \multirow[t]{2}{*}{5} & Masjid & $\$$ & $1,781.49$ & $1,781.49$ & $\$$ & - & $\$$ \\
\hline & Total & $\$$ & $5,565,735.66$ & $\$ 5,663,473.07$ & $\$$ & $97,737.41$ & $24,434.35$ \\
\hline No. & $\begin{array}{c}\text { Aset Tetap } \\
2012\end{array}$ & & $\begin{array}{c}\text { PV } \\
\text { Garis Lurus }\end{array}$ & $\begin{array}{c}\text { PV } \\
\text { Saldo Menurun }\end{array}$ & \multicolumn{2}{|r|}{ Selish } & Penghematan PPh \\
\hline 1 & Mesin & $\$$ & $4,876,547.09$ & $\$ 1,505,156.36$ & $\$$ & $(3,371,390.73)$ & $\$ \quad(842,847.68)$ \\
\hline 2 & Inventaris Kantor & $\$$ & $976,261.88$ & $214,644.57$ & $\$$ & $(761,617.31)$ & $\$ \quad(190,404.33)$ \\
\hline 3 & Kendaraan & $\$$ & $146,961.64$ & $(14,337.34)$ & $\$$ & $(161,298.98)$ & $\$ \quad(40,324.75)$ \\
\hline 4 & Bangunan dan Listrik & $\$$ & $496,459.23$ & $461,661.90$ & $\$$ & $(34,797.33)$ & $(8,699.33)$ \\
\hline \multirow[t]{2}{*}{5} & Masjid & $\$$ & $(94.42)$ & $(89.29)$ & $\$$ & 5.13 & 1.28 \\
\hline & Total & $\$$ & $6,496,135.42$ & $\$ 2,167,036.20$ & $\$$ & $(4,329,099.22)$ & $\$(1,082,274.81)$ \\
\hline No. & $\begin{array}{c}\text { Aset Tetap } \\
2013 \\
\end{array}$ & & $\begin{array}{c}\text { PV } \\
\text { Garis Lurus } \\
\end{array}$ & $\begin{array}{c}\text { PV } \\
\text { Saldo Menurun } \\
\end{array}$ & & Selish & Penghematan PPh \\
\hline 1 & Mesin & $\$$ & $5,102,447.70$ & $\$(2,705,934.81)$ & $\$$ & $(7,808,382.51)$ & $\$ \quad(1,952,095.63)$ \\
\hline 2 & Inventaris Kantor & $\$$ & $998,186.70$ & $\$ \quad(673,583.98)$ & $\$$ & $(1,671,770.68)$ & $(417,942.67)$ \\
\hline 3 & Kendaraan & $\$$ & $121,828.94$ & $\$ \quad 321,809.27$ & $\$$ & $199,980.33$ & $49,995.08$ \\
\hline 4 & Bangunan dan Listrik & $\$$ & $499,678.67$ & $\$ 440,822.42$ & $\$$ & $(58,856.25)$ & $(14,714.06)$ \\
\hline \multirow[t]{2}{*}{5} & Masjid & $\$$ & $1,756.63$ & $1,668.80$ & $\$$ & $(87.83)$ & $(21.96)$ \\
\hline & Total & $\$$ & $6,723,898.64$ & $\$(2,615,218.30)$ & $\$$ & $(9,339,116.94)$ & $\$(2,334,779.24)$ \\
\hline
\end{tabular}

(Sumber: PT. Citra Abadi Sejati, data diolah penulis)

Dari tabel 2 dapat dilihat potensi kehematan pajak penghasilan PPh badan yang dapat di peroleh oleh perusahaan dengan tarif pajak $25 \%$ pada tahun 20102013, maka kesimpulan dari tabel tersebut adalah pada 2010 perusahaan dapat memperoleh penghematan $\mathrm{PPh}$ sebesar \$2,403,548.44, pada tahun 2011 $\mathrm{PPh}$ badan yang dapat dihemat sebesar \$ 24,434.35, pada tahun $2012 \mathrm{PPh}$ yang di hemat sebesar $\$(1,082,274.81)$ dan pada tahun 2013 perusahaan kembali dapat menghemat $\mathrm{PPh}$ badan sebesar \$ $(2,334,779.24)$ Jumlah penghematan ini didapat dengan cara jumlah present value metode garis lurus dikurang dengan present value metode saldo menurun sehingga didapatkan selisih antara kedua metode tersebut, jumlah dari selisih tersebut dikalikan dengan tarif pajak yaitu $25 \%$ sehingga didapatkan penghematan $\mathrm{PPh}$ badan.

\section{Penutup}

\subsection{Kesimpulan}

Berdasarkan pembahasan di bab sebelumnya, maka dapat ditarik kesimpulan sebagai berkut :

1. Kebijakan penyusutan aset tetap pada PT. Citra abadi Sejati telah sesuai dengan peraturan perpajakan, karena telah sesuai dengan pasal yang berlaku saat ini yaitu pasal 11 ayat (1) dan ayat (2) UU No. 36 Tahun 2008 mengenai metode penyusutan yang diperkenankan oleh perpajakan (garis lurus dan saldo menurun)dan perusahaan dalam laporan fiskalnya telah menerapkan metode penyusutan garis lurus untuk penyusutan asetnya.

2. Penerapan metode penyusutan aset tetap lainya yang sesuai dengan peraturan perpajakan sangat 
mungkin untuk diterapkan pada PT. Citra Abadi Sejati karena jika menggunakan metode penyusutan yang berbeda dari metode penyusutan yang digunakan saat ini oleh perusahaan, berdasarkan hasil perhitungan beban penyusutan aset tetap. Beban penyusutan aset tetap dengan menggunakan metode garis lurus tahun $2010 \quad \$ \quad 5,504,724.40$ sedangkan dengan metode saldo menurun sebesar $\$ 15,118,918.14$ sehingga terdapat selisih sebesar \$ 9,614,193.7, tahun 2011 \$ $5,565,735.66$ sedangkan metode saldo menurun sebesar \$ 5,663,473.07 sehingga terdapat selisih sebesar $\$ 97,737.41$, tahun 2012 sebesar \$ \$ 6,496,135.42 sedangnkan dengan metode saldo sebesar \$2,167,125.49 sehingga terdapat selisih sebesar \$ 4,329,009.93, dan tahun 2013 sebesar sebesar $\$ 6,723,898.64$ dengan metode saldo menurun sebesar \$2,616,887.10 sehingga terdapat selisih sebesar \$ 4,107,011.54.

3. Perencanaan pajak aset tetap berpengaruh terhadap besarnya $\mathrm{PPh}$ badan, maka oleh sebab itu sebaiknya PT. Citra abadi Sejati menerapkan perencanaan pajak aset tetap agar beban pajak perusahaan lebih efisien, berdasarkan hasil perhitungan di bab sebelumnya berikut ini penghematan beban pajak yang dapat dirasakan oleh perusahaan jika menerapkan perencanaan pajak atas aset tetapnya sebagai berikut ini yaitu pada 2010 potensi kehematan beban pajak adalah sebesar \$2,403,584.44 atau sebesar 34\%, pada tahun 2011 potensi kehematan beban pajak sebesar \$24,434.35 atau sebesar
10\%, pada tahun 2012 potensi kehematan beban pajak sebesar $\$$ $(1,082,274.81)$ atau sebesar 52\%, dan pada tahun 2013 potensi kehematan beban pajak sebesar \$ $(2,334,779.24)$ atau sebesar $31 \%$.

\subsection{Saran}

Berdasarkan kesimpulan yang telah dibahas diatas sebelumnya maka penulis mencoba untuk memberikan saran atau masukan sebagai bahan pertimbangan :

1. Bagi manajemen PT. Citra Abadi Sejati :

Berdasarkan analisis yang telah dilakukan penulis, seharusnya PT. Citra Abadi Sejati melakukan perencanaan pajak khusus dengan menerapkan metode penyusutan saldo menurun terhadap aset tetapnya karena masih terdapat celah dalam meminimalisasikan beban pajak PT. Citra Abadi Sejati yang tidak melanggar undangundang perpajakan yaitu dengan cara memilih metode penyusutan yang tepat dalam perhitungan penyusutan aset tetap perusahaan sehingga dapat memperkecil beban pajak penghasilan PT. Citra Abadi Sejati

2. Bagi peneliti selanjutnya :

Bagi siapa saja yang tertarik untuk melakukan penelitian lebih lanjut dengan judul yang sama, disarankan melakukan penelitian dan menganalisi faktor-faktor perencanaan pajak lainnya yang dapat diterapkan pada PT. Citra Abadi Sejati dan yang sekiranya dapat mengefisiensikan beban pajak penghasilan badan, seperti revaluasi aset tetap, pemberian kesejahteraan kepada karyawan dalam bentuk cash atau natura dan lain sebagainya. 
DAFTAR PUSTAKA

Direktorat jenderal pajak.2008.Undang - undang No.36 Tahun 2008

Direktorat jenderal pajak.2008.Undang - undang No.36 Tahun 2008 tentang Perubahan keempat atas Undang - undang No. 7 Tahun 1983 tentang Pajak Penghasilan. Jakarta

Direktorat Jenderal Pajak 2007. Undang - undang Nomor 28 Tahun 2007 tentang perubahan Ketiga Atas Undang - undang Nomor 6 Tahun 1983 Tentang ketentuan Umum dan Tata Cara Perpajakan.

Diana, Anastasia dan Setiawati,Lilis. 2009. Perpajakan Indonesia. Andi Offset: Yogyakarta

Muljono, Djoko.2009. Tax Planning Menyiasati Pajak dengan Bijak. Yogyakarta: Andi Offset

Pudyatmoko, Y. Sri. 2006. Pengantar Hukum Pajak. Yogyakarta: Andy Offset.

Purba. Rinaldhie. 2012 Sistem Perpajakan di Indonesia Saat Ini

Pernyataan Standar Akuntansi Keuangan No.30 ( Revisi 2009 ) Tentang Definisi Sewa
Suandy, Erly.2013. Perencanaan Pajak edisi Kelima. Jakarta: Salemba Empat.

2011. Perencanaan Pajak Edisi Keempat. Jakarta: Salemba Empat.

2008. Perencanaan Pajak Edisi Keempat. Jakarta: Salemba Empat.

2006. Perencanaan Pajak Edisi Keempat. Jakarta: Salemba Empat.

Sugiyono. 2011. Metode Penelitian Kuantitatif Kualitatif dan $R \& D$. Bandung: Alfabeta

Thomas Sumarsan. 2013. Tax Review dan Strategi Perencanaan Pajak (ed 2). PT. INDEKS, Jakarta.

Undang - Undang Republik Indonesia Nomor 36 Tahun 2008 Tentang Pajak Penghasilan.

Yustinus Prastowo. 2011. Panduan Lengkap Pajak. Raih Asa Sukses, Depok.

Zain, Mohammad. 2008. Manajemen Perpajakan. Jakarta: Salemba Empat. 